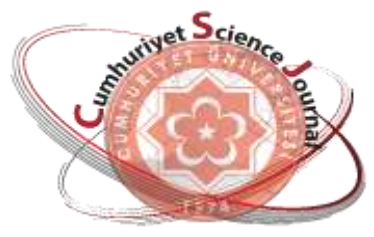

e-ISSN: $2587-246 X$

ISSN: $2587-2680$

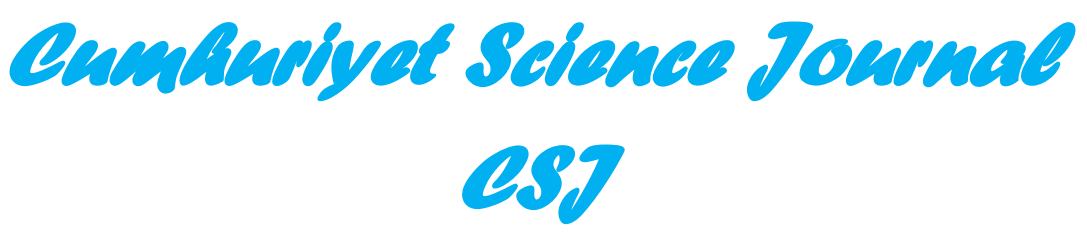

Cumhuriyet Sci. J., Vol.39-1(2018) 233-242

\title{
Effect of Cold Rolling Reduction Rate on Corrosion Behaviour of Twin-roll Cast 8006 Aluminium Alloys
}

\author{
Israfil KUCUK \\ Bursa Technical University, Faculty of Natural Sciences, Architecture and Engineering, Dept. of Metallurgical and Materials \\ Engineering, Bursa, TURKEY
}

Received: 05.02.2018; Accepted: 22.02.2018

http://dx.doi.org/10.17776/csj.390178

\begin{abstract}
Utilization of aluminum alloys in the automotive industry takes a crucial role in recent years due to their excellent properties such as corrosion resistance and light weight. 3003 and 8006 aluminum alloys have been particularly used as a heat exchanger compartment due to their corrosion resistance feature which has a perfect match for a heat exchanger fin stocks and a destructive salty environment in this car's part. In the present work, an effect of cold rolling reduction (CRR) rate on the corrosion twin-roll cast 8006 aluminium alloys was investigated. Firstly, the aluminium alloy was submitted to twin-roll casting process to achieve $8.5 \mathrm{~mm}$ thickness sheet. Then, homogenization annealing was applied between $550{ }^{\circ} \mathrm{C}$ and $600{ }^{\circ} \mathrm{C}$. Subsequently, two cold rolling routes were subjected at different CRR rates of $94 \%$ and $98 \%$, respectively. Finally, the aluminium sheets were annealed between $400{ }^{\circ} \mathrm{C}$ and $450{ }^{\circ} \mathrm{C}$ for $60 \mathrm{~min}$. in a furnace for electrochemical corrosion tests. Electrochemical corrosion tests were performed in $1 \mathrm{M} \mathrm{NaCl}$ and $\mathrm{H}_{2} \mathrm{O}_{2}$ solution, and open circuit potential and polarization curves were successfully achieved. The surface features of the specimens before and after corrosion tests were assessed using stereomicroscopy and 3D profilometer. Based on the results, an increase in the various CRR rates depending on cold rolling route applied decreases the corrosion resistance of the twin-roll cast 8006 aluminum alloys. Thus, they could be very versatile materials for heat exchanger fin stock materials.
\end{abstract}

Keywords: Twin-roll cast aluminium, 8006, corrosion, polarization curves, cold rolling reduction rate

\section{İkiz Merdane Sürekli Döküm 8006 Alüminyum Alaşımlarının Korozyon Davranışına Soğuk Hadde Ezme Oranının Etkisi}

Özet: Alüminyum malzemelerin, korozyon direnci ve hafiflik gibi harika özelliklerinden dolay1, otomotiv sektöründe kullanımı son yıllarda önemli bir yer tutmaktadır. Özellikle 1sı eşanjörü (heat exchanger) elemanı olarak 3003, 8006 grubu hadde alüminyum alaşımlarının kullanımı, eşanjörlerin korozif bir sıvı ortamı içermesinden dolayı ve bu malzemelerin korozyon özelliklerinden dolayı tercih edilmektedir. Bu çalışmada, ikiz merdane sürekli döküm yöntemi ile elde edilen 8006 grubu alüminyum alaşımlarının korozyon özelliklerine soğuk haddeleme ezme oranının etkisi incelenmiştir. 8006 Alüminyum alaşımı, öncelikle soğuk deformasyon haddesi olan ikiz merdanelerin arasına $8.5 \mathrm{~mm}$ kalınlıkta levha olarak döküldü ve ardından 550 ila $600{ }^{\circ} \mathrm{C}$ arasında homojenleştirme tavlamasına tabi tutuldu. Hemen ardından ezme oranı farklı olan iki haddeleme işlemine tabi tutularak sırasıyla, $\% 94$ ve $\% 98$ oranında bir ezme işlemi uygulandı. Nihai olarak, 400 oC ila 450 $\mathrm{oC}$ arasında bir sıcaklıkta normalizasyon tavlamasına maruz birakıldı. Elde edilen numunelerin yüzeyi, $1 \mathrm{M}$ $\mathrm{NaCI}+\mathrm{H}_{2} \mathrm{O}_{2}$ içeren çözeltide korozyon testleri (açık devre potansiyeli ölçümü ve polarizasyon eğrileri eldesi)

* Corresponding author. Email address: israfil.kucuk@btu.edu.tr

http://dergipark.gov.tr/csj C $\quad$ (2016 Faculty of Science, Cumhuriyet University 
öncesi ve sonrası, stereo mikroskop ile yüzey görünümü analizine tabi tutuldu ardından 3B yüzey pürüzlülük ölçümü yöntemi kullanılarak, yüzey pürüzlülüğü analizi gerçekleştirildi. Elde edilen sonuçlara göre, soğuk deformasyon işlemine bağlı olarak uygulanan farklı ezme oranındaki artışın ikiz merdane sürekli döküm yöntemi ile elde edilen 8006 alüminyum alaşımlarının korozyon davranışında azalmaya bağlı olarak, korozyon direncinin arttı̆̆ını göstermiştir.

Anahtar Kelimeler: İkiz merdane sürekli döküm alüminyum, 8006, korozyon, polarizasyon eğrileri, soğuk hadde ezme oranı

\section{INTRODUCTION}

Metal alloy fabrication or structure manufacturing processes, including rolling, extrusion, mechanical grinding, and machining generally subjects high shear deformation to the surface region of aluminium products which brings about various surface roughness profiles on the surface features [1-5]. Each cold rolling reduction deformation (CRRD) technique such as conventional cold rolling, reversing cold rolling, and twin roll casting (TRC) results in significantly different depth mapping characteristics as well as surface roughness on the surface of cold-rolled aluminium alloys [6-10].

A one of the CRRD techniques, twin-roll casting (TRC), has a significant role in the determination of the surface features of aluminium alloys [8, 11]. The presence of the surface cold reduced region obtained by TRC may crucially affect the corrosion performance of aluminium alloys due to the presence of high dislocation density, residual stress, alloying element segregation at the grain boundaries and surface roughness $[12,13]$. Le et al. [8] reported that with an increase in the cold rolling reduction rate, longer wavelengths of roughness could be crushed more easily which could improve the corrosion resistance of aluminium alloys.

8006 aluminium alloys are widely used for manufacturing the packaging foils and sheets for common heat exchanger applications [13, 14]. Increasing demands of the industry on corrosion resistance, mechanical properties and formability has evoked an intensive investigation of sheets and foils with an influence of cold rolling reduction rate [15-17]. Although TRC aluminium alloy sheets and foils are optimal candidates for further cold rolling reduction process, there is no available data on an influence of CRR rates on TRC 8006 aluminium alloy's corrosion properties. Also, corrosion characteristics of various aluminium alloys produced by TRC resulting surface roughness profiles has been subjected to attention for the past decades because of its importance in pitting corrosion resistance $[2,6,13,15]$. The present work is aimed to study the effect of cold rolling reduction rate as that achieved during the twin-roll casting process, on corrosion behaviour of 8006 aluminium alloys in $1 \mathrm{M} \mathrm{NaCI}$ aqueous solution environment.

\section{EXPERIMENTAL PROCEDURES}

\subsection{Specimens and surface preparations}

Twin-roll cast (TRC) 8006 aluminium alloys with two different thicknesses provided by Assan Aluminium Company was used as the base material. The composition (wt. \%) of the TRC 8006 aluminium alloys are listed in Hata! Başvuru kaynağı bulunamadı.. At the end of production process, comprising the TRC casting with a thickness of $8.5 \mathrm{~mm}$, homogenization annealing performed between $550{ }^{\circ} \mathrm{C}$ and $600{ }^{\circ} \mathrm{C}$ and, the two different final thicknesses $(150 \mu \mathrm{m}$ or $180 \mu \mathrm{m}$ ) of the TRC 8006 aluminium alloy sheets were obtained. Prior to experiments, the 
aluminium sheet samples were ultimately annealed between $400{ }^{\circ} \mathrm{C}$ and $450{ }^{\circ} \mathrm{C}$ for $60 \mathrm{~min}$. in a furnace to gain a homogenous microstructure.

After twin-roll casting processing and homogenization annealing, the TRC 8006 aluminium sheets were cold deformed in one direction between working the rolls to gradually reduce their thickness after numerous successive passes. The plates were cold rolled to a $94 \%$, and $98 \%$ reduction in its thickness. Then, the samples were cut into $5 \mathrm{~cm} \times 5 \mathrm{~cm}$, with surfaces parallel to the rolling direction. All samples were sequentially rinsed in acetone and 2-propanol with ultrasonic cleaner for $5 \mathrm{~min}$. at room temperature and dried before the electrochemical measurements.

Table 1. Chemical composition of the Twin-roll cast 8006 aluminium alloy used (wt. \%).

\begin{tabular}{llllllllll}
\hline Sample & Fe & Si & Cu & Mn & Mg & Cr & Zn & Ti & Al \\
\hline TRC 8006 & 1.50 & 1.130 & 0.020 & 0.80 & 0.0025 & 0.0037 & 0.020 & 0.15 & Balance \\
\hline
\end{tabular}

\subsection{Electrochemical analysis}

Electrochemical measurements have been employed to assess corrosion susceptibility of TRC 8006 aluminium alloys in the heat exchanger environments. Tests were performed using a Gamry's conventional three-electrode cell system (model PC14/750 Potentiostat/ Galvanostat/ ZRA), in $1 \mathrm{M} \mathrm{NaCI}$ solution of $\mathrm{pH} 5.5$ according to ASTM G69-12, aerated for $60 \mathrm{~min}$. by magnetic mixer, before start (Figure 1). The cell was assembled with the TRC 8006 aluminium sample as working electrode (WE), a saturated calomel electrode was used as a reference (RE) and a graphite rod was used as an auxiliary electrode (AE). Exposed areas for working and auxiliary electrode were $0.785 \mathrm{~cm}^{2}$.
The open-circuit potential (OCP) was recorded for 6000 seconds waiting, in any case, to investigate how long the OCP value of the samples reaches a steady state. Polarization curves were recorded in a single sweep starting from $-0.5 \mathrm{~V}$ versus OCP going as high as $0.5 \mathrm{~V}$ versus OCP. The scan rate was $0.20 \mathrm{mV} / \mathrm{s}$. The measurements were conducted at room temperature $\left(25{ }^{\circ} \mathrm{C}\right)$. From this experiment, $\mathrm{I}_{\text {corr }}$ and $\mathrm{E}_{\mathrm{corr}}$ values were measured using Tafel plot and the corrosion rate in milli-inches per year (mpy) was determined. All trials were repeated three times to ensure reproducibility and accuracy of the measurements. 


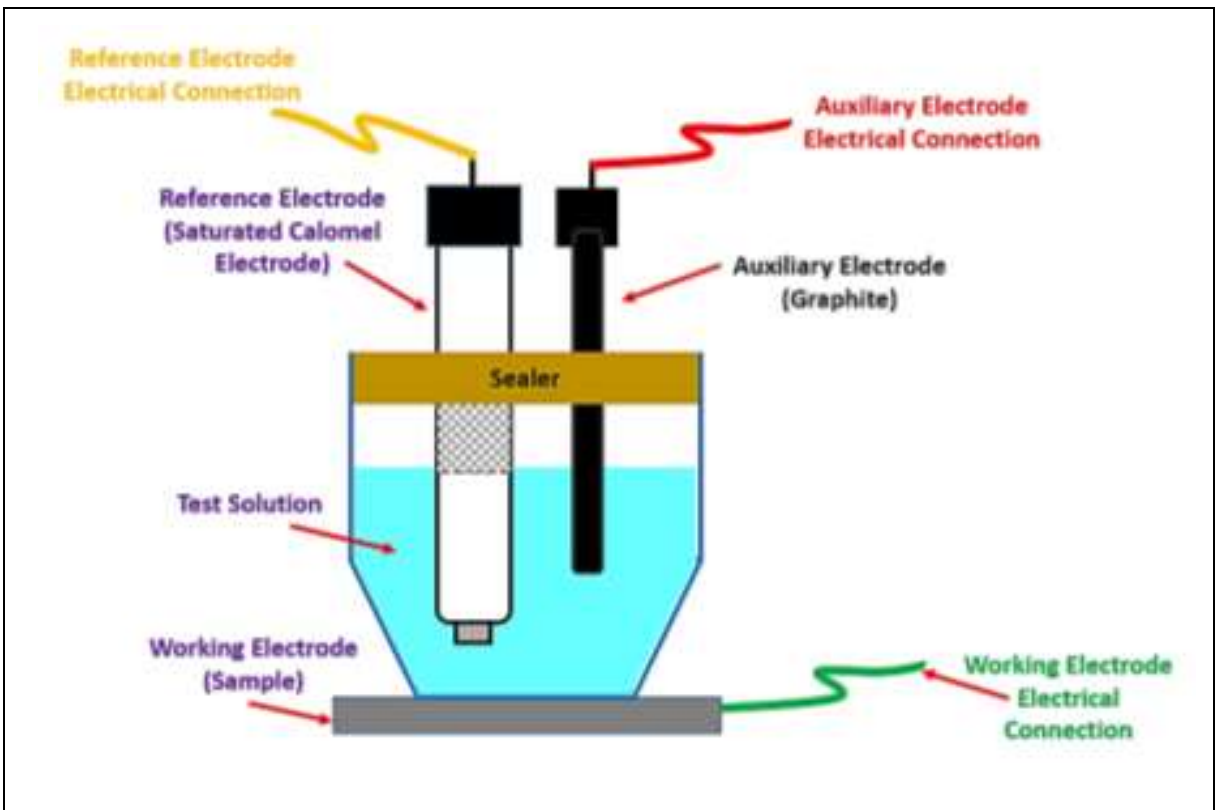

Figure 1. A typical three electrodes paint-cell used for electrochemical testing

\subsection{Electrochemical analysis}

Electrochemical measurements have been employed to assess corrosion susceptibility of TRC 8006 aluminium alloys in the heat exchanger environments. Tests were performed using a Gamry's conventional three-electrode cell system (model PC14/750 Potentiostat/ Galvanostat/ ZRA), in $1 \mathrm{M} \mathrm{NaCI}$ solution of $\mathrm{pH} 5.5$ according to ASTM G69-12, aerated for $60 \mathrm{~min}$. by magnetic mixer, before start (Figure 1). The cell was assembled with the TRC 8006 aluminium sample as working electrode (WE), a saturated calomel electrode was used as a reference (RE) and a graphite rod was used as an auxiliary electrode (AE). Exposed areas for working and auxiliary electrode were $0.785 \mathrm{~cm}^{2}$.

The open-circuit potential (OCP) was recorded for 6000 seconds waiting, in any case, to investigate how long the OCP value of the samples reaches a steady state. Polarization curves were recorded in a single sweep starting from $-0.5 \mathrm{~V}$ versus OCP going as high as $0.5 \mathrm{~V}$ versus OCP. The scan rate was $0.20 \mathrm{mV} / \mathrm{s}$. The measurements were conducted at room temperature $\left(25^{\circ} \mathrm{C}\right)$. From this experiment, $\mathrm{I}_{\text {corr }}$ and $\mathrm{E}_{\text {corr }}$ values were measured using Tafel plot and the corrosion rate in milli-inches per year (mpy) was determined. All trials were repeated three times to ensure reproducibility and accuracy of the measurements.

\subsection{Microstructure and surface observations}

The surface morphology evolution was analysed using stereomicroscopy (Nikon SMZ

1500, Tokyo, Japan) and 3D optical microscopy (Bruker Contour GT-I, Germany). 3D optical microscope was applied to determine 3D surface profiles of the TRC 8006 aluminium alloys with the different cold rolling reduction rates. For stereomicroscope examination of the samples before and after corrosion tests, specimens were rinsed with distilled water. 


\section{RESULTS and DISCUSSION}

\subsection{Surface morphology investigation}

A characteristic rolling topography and contained a number of defects in the form of transverse cracks, shingles and holes were observed throughout the surfaces of the cold rolling reduced TRC 8006 aluminium alloys before exposure to the solution, shown in Figure 2. Moreover, surface profiles were qualitatively characterized by 3D optical microscopy images. The depth mapping images through the specimen' surface were depicted in Figure 3(a) and (b) showed an influence of cold rolling reduction (CRR) rate on the surface topography. Figure 3(a)

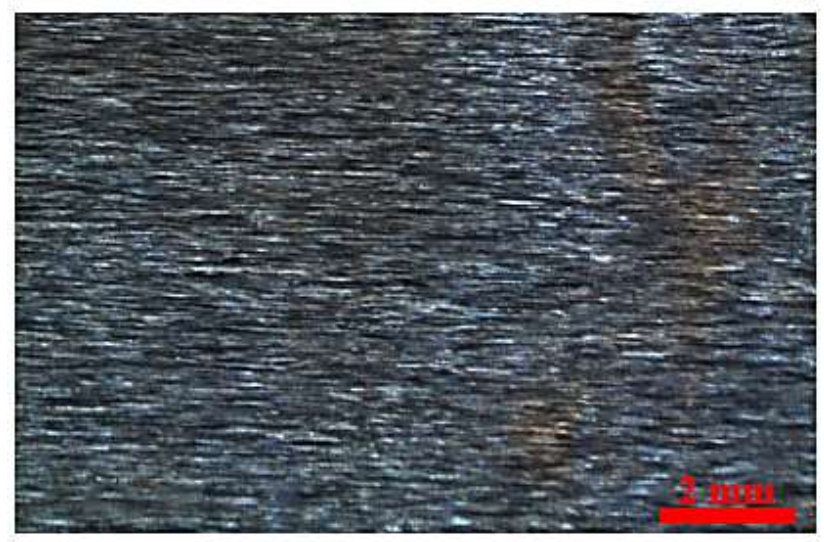

(a) depicted the surface topographical changes of the TRC 8006 aluminium alloy with a CRR of $94 \%$. In Figure 3(a), small hills were presented on the surface of the specimen and surface roughness $\left(R_{a}\right)$ value was $0.554 \mu \mathrm{m}$. Figure 3(b) showed the surface morphology of the TRC 8006 aluminium alloy with a CRR of $98 \%$ which has more cold rolling reduction rate compared to the one with a CRR of 94\%. Compared to the TRC 8006 with a CRR of $94 \%$ sample, smaller hills were captured on the surface topography and a lower surface roughness value which is about $0.344 \mu \mathrm{m}$ (Figure $3(\mathrm{~b}))$.

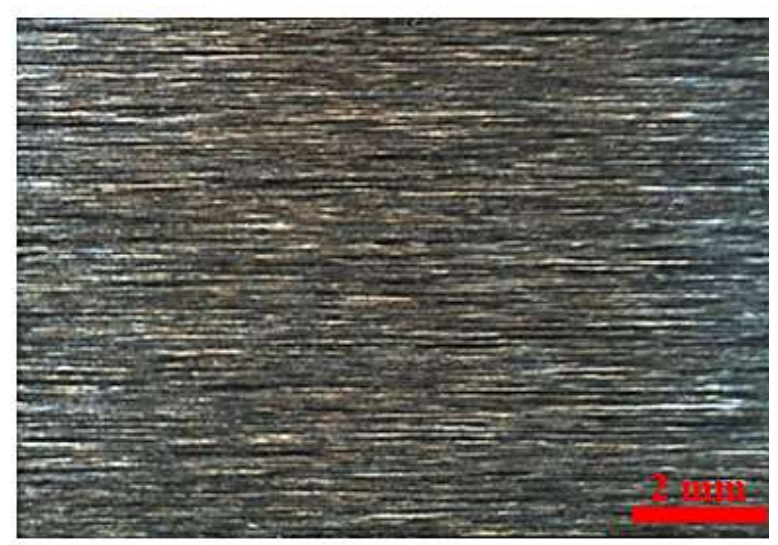

(b)

Figure 2. Stereo microscopy images of TRC 8006 aluminium alloys before corrosion tests applied: thickness of a) $150 \mu \mathrm{m}$ and b) $180 \mu \mathrm{m}$. 


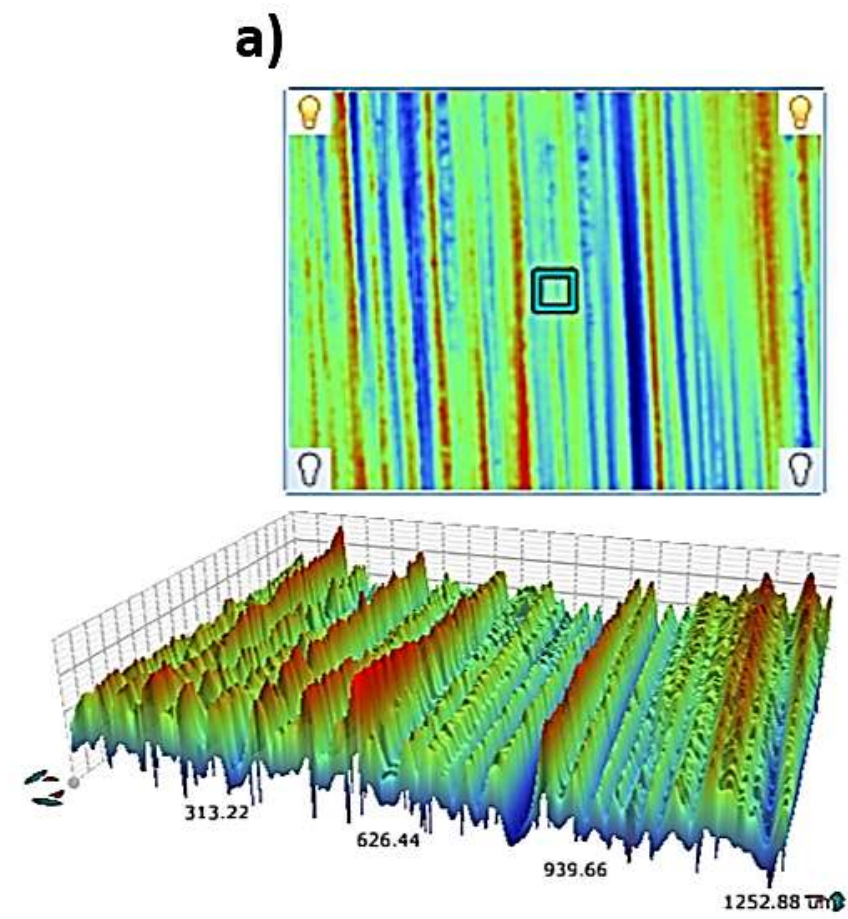

b)
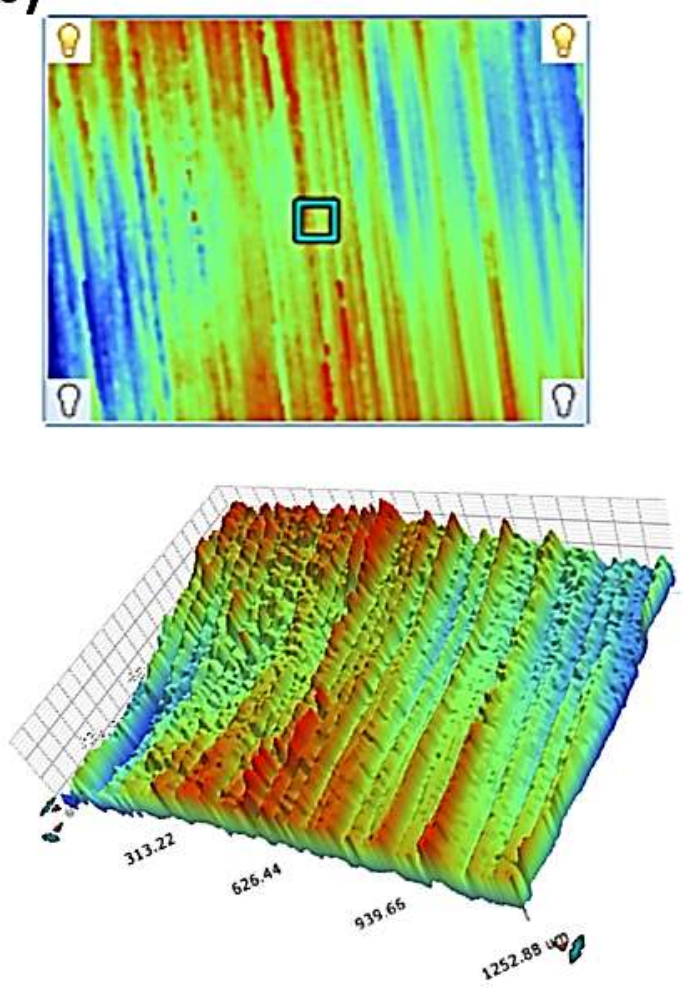

Figure 3. 3D topography images of the TRC 8006 aluminium alloys used: a CRR of $94 \%$ (a) and 98\% (b).

\subsection{Open-circuit potential results}

Corrosion potential data given in Figure 4 show that the TRC 8006 aluminium alloys with two different cold rolling reduction rates, the TRC 8006 aluminium alloy exhibited a relatively stable potential around $-780 \mathrm{mV}_{\mathrm{SCE}}$, close to the reported critical pitting potential values of aluminium [18]. Cold rolling reduction at increasing reduction rates up to $98 \%$ caused the formation of much deeper transients of increased longevity in the corrosion potential, starting from an increasingly negative potential and lasting for approximately half an hour before the potential stabilised at a rest potential similar to that of the TRC 8006 aluminium alloy with a CRR of $94 \%$. The initial potentials of the high cold rolled samples were close to $-980 \mathrm{mV}_{\text {SCE }}$ and increased slowly towards a rest potential near that of the TRC 8006 aluminium alloy with a CRR of $94 \%$ sample over nearly an hour. Both samples had a monotonically characteristic increase towards the rest potential. 


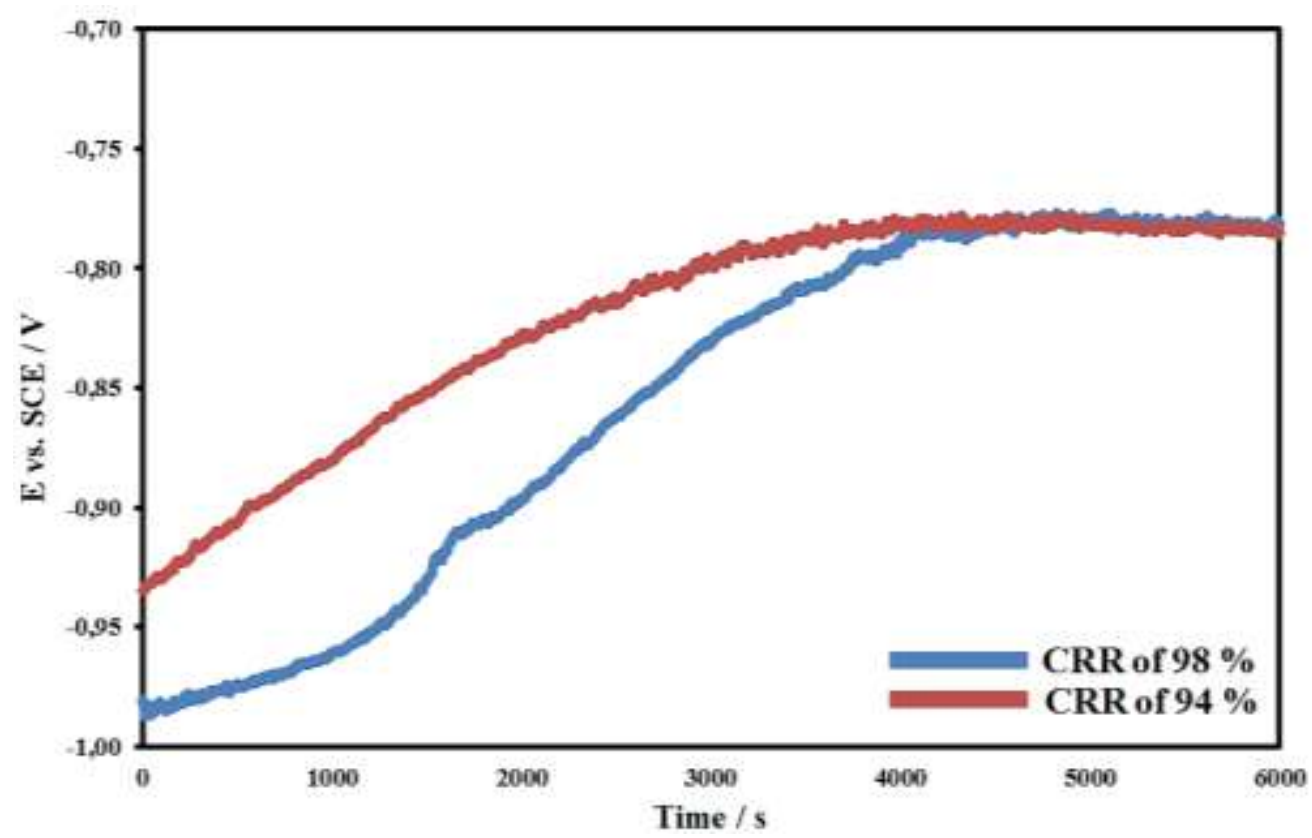

Figure 4. Corrosion potential vs. exposure time in $1 \mathrm{M} \mathrm{NaCI}$ solution for the TRC 8006 aluminium alloys with different cold rolling reduction $(\mathrm{CRR})$ rates.

\subsection{Polarization curve measurements}

A comparison of polarization curves for different cold rolling reduction (CRR) rates done is shown in Figure 5. With the increase of cold rolling reduction $(\mathrm{CRR})$ value, the corrosion potential of the specimen decreased and anodic dissolution current density increased. Cathodic current density increased as the CRR value reached 98\% (Figure 5). It can be seen that an increase in CRR rate for TRC 8006 aluminium alloys used improved the corrosion resistance of the specimens. Moreover, TRC 8006 aluminium alloys would not be passivated in the $1 \mathrm{M} \mathrm{NaCI}$ aqueous solution containing $\mathrm{H}_{2} \mathrm{O}_{2}$.
The electrochemical parameters, including corrosion current density, corrosion potential, anodic and cathodic Tafel slopes are fitted and listed in Hata! Başvuru kaynağı bulunamadı.. The corrosion rate in mpy was determined from the $\mathrm{E}_{\text {corr }}$ and $\mathrm{I}_{\text {corr }}$ values measured from the Tafel plots as per the ASTM Standard G69-12 [19]. The results obtained clearly indicated that an improvement in corrosion resistance can be explained by the help of surface roughness. There may be the presence of shorter wavelength of highly cold rolled TRC 8006 aluminium alloys which provides initial corrosive attack regions on Al-rich phases forming a protective layer.

Table 2. Fitted electrochemical parameters at different cold rolling reduction CRR rate.

\begin{tabular}{ccccc}
\hline CRR $(\%)$ & $\mathbf{E}_{\text {corr }}$ vs. SCE $(\mathbf{m V})$ & $\left.\mathbf{i}_{\text {corr }}(\boldsymbol{\mu A . . c m})^{-2}\right)$ & $\begin{array}{c}\mathbf{b}_{\mathbf{a}} \text { vs. SCE } \\
\left(\mathbf{x 1 0}^{-3} \text { V/decade }\right)\end{array}$ & $\begin{array}{c}\mathbf{b}_{\mathbf{c}} \text { vs. SCE } \\
\left(\mathbf{x 1 0}^{-3} \text { V/decade }\right)\end{array}$ \\
\hline 94 & -796 & 1450 & 781.3 & 665.8 \\
98 & -714 & 126 & 67.50 & 174.2 \\
\hline
\end{tabular}




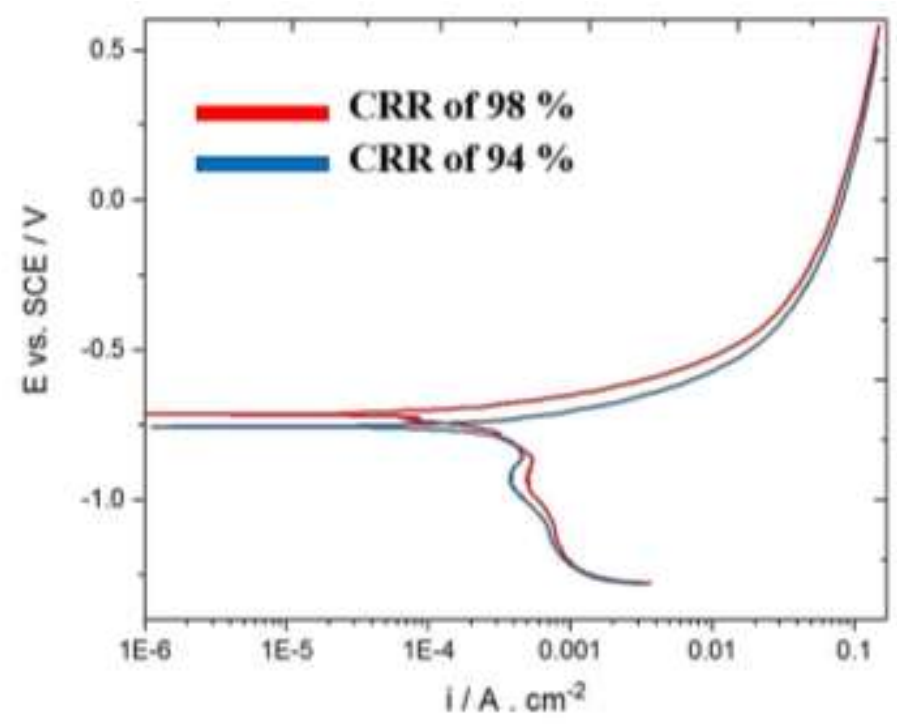

Figure 5. Effect of cold rolling reduction rate on the polarization behaviour of TRC 8006 aluminium alloys in $1 \mathrm{M}$ NaCI solution containing 5 wt. $\% \mathrm{NaCI}$ and $2.52 \mathrm{ml} \mathrm{H}_{2} \mathrm{O}_{2}$ at room temperature.

\subsection{Surface characterization after corrosion tests}

An effect of cold rolling reduction rate on the corrosion morphology of the cold rolling reduced samples was investigated in the $1 \mathrm{M} \mathrm{NaCI}$ aqueous solution. Figure 6 shows the stereomicroscope images of the surface morphology for the TRC 8006 aluminium alloys with different CRR values after polarization curve measurements in the test environment, $1 \mathrm{M} \mathrm{NaCI}$ aqueous solution. In general the mode of corrosion was that of localised crystallographic attacks extending

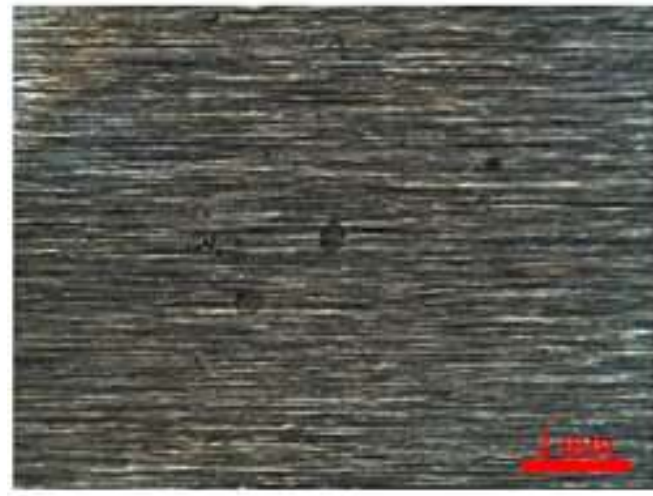

(a) mostly in the rolling direction. The pits observed were in rounded or elliptic shape (Figure 6). Figure 6(a) presents the surface morphology of the TRC 8006 aluminium alloy with a CRR of $94 \%$. It is clearly seen that several pits appeared with large pit mouth. Figure 6(b) shows the surface view of the TRC 8006 aluminium alloy with a CRR of 98\%. In Figure 66b, many pits with smaller pit mouth compared to the other one can be clearly seen. With CRR value rising, pit sizes tended to decrease, while the pit number and pit size distribution was increased.

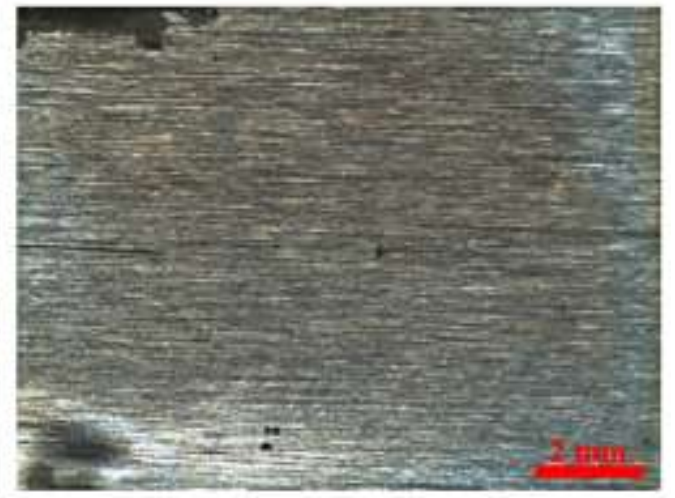

(b)

Figure 6. Stereo microscopy images of TRC 8006 aluminium alloys after corrosion tests applied: CRR of a) $94 \%$ and b) $98 \%$. 


\section{CONCLUSIONS}

Twin-roll cast 8006 aluminium alloy with different cold rolling reduction rates of $94 \%$ and $98 \%$ has been studied. Major conclusions drawn from the work are summarised below:

- Shorter wavelength of roughness, less surface defects like cracks, shingles and holes were noticed on the surface of the TRC 8006 aluminium alloy with a CRR rate of $98 \%$ compared to that of $94 \%$. This may improve the surface corrosion resistance and thus benefit in handling of good heat exchanger aluminium foils.

- The TRC 8006 with $98 \%$ showed better corrosion resistance than the other with $94 \%$ in $1 \mathrm{M} \mathrm{NaCI}$ aqueous solution.

- Pitting size and distribution on the surface of the TRC 8006 with $98 \%$ in $1 \mathrm{M} \mathrm{NaCI}$ aqueous solution was appreciably less than that of the TRC 8006 with $94 \%$ and thereby the improvement in cold rolling reduction rate may result in higher corrosion resistance.

\section{REFERENCES}

[1]. Liu B., Zhang X., Zhou X., Hashimoto T., Wang J., The Corrosion Behaviour of Machined AA7150-T651 Aluminium Alloy, Corrosion Science, 126 (2017) 265-271.

[2]. Wang J., Zhou X., Thompson G.E., Hunter J.A., Yuan Y., Near-Surface Microstructure on Twin-Roll Cast 8906 Aluminum Alloy, Metallurgical and Materials Transactions, A 46-6 (2015) 2688-2695.

[3]. Wang J., Zhou X., Thompson G.E., Hunter J.A., Yuan Y., Microstructure Evolution in the Near-Surface Region During Homogenization of a Twin-Roll Cast AlFeMnSi Alloy, Metallurgical and
Materials Transactions, A 47-8 (2016) 42684275.

[4]. Imamura T., Shingaki Y., Hayakawa Y., Effect of Cold Rolling Reduction Rate on Secondary Recrystallized Texture in 3 Pct $\mathrm{Si}-\mathrm{Fe}$ Steel, Metallurgical and materials transactions, A 44-4 (2013) 1785-1792.

[5]. Georgiou E., Celis J.-P., Panagopoulos C., The Effect of Cold Rolling on the Hydrogen Susceptibility of 5083 Aluminum Alloy, Metals, 7-11 (2017) 451.

[6]. Delijić K., Markoli B., Naglič I., The Influence of the Chemical Composition on the Corrosion Performances of Some Al-Fe$\mathrm{Si}, \mathrm{Al}-\mathrm{Mg}-\mathrm{Si}$ and Al-Mg-Mn Type of Alloys, Metallurgical and Materials Engineering, 204 (2014) 217-234.

[7]. Ramirez A.H., Ramirez C.H., Costa I., Cold Rolling Effect on the Microstructure and Pitting Resistance of the NBr ISO 5832-1 Austenitic Stainless Steel, International Journal of Electrochemical Science, 8-12 (2013) 12801-12815.

[8]. Le H., Sutcliffe M., Analysis of Surface Roughness of Cold-Rolled Aluminium Foil, Wear, 244-1 (2000) 71-78.

[9]. Sanders R.E., Continuous Casting for Aluminum Sheet: a Product Perspective, JOM, 64-2 (2012) 291-301.

[10].Birol F., Birol Y., Corrosion of Twin Belt and Twin Roll Cast AlMg3Mn Alloys, Corrosion Engineering, Science and Technology, 49-3 (2014) 228-235.

[11].Kikkawa T., New Rolling Method of Reversing Cold Rolling Mill, Proc. AISTech, 2012 (2012) 1771-1780.

[12].Rahimi M., Fojan P., Gurevich L., Afshari A., Aluminium Alloy 8011: Surface Characteristics, Applied Mechanics and Materials, Trans Tech Publ, 2015, pp. 29-37.

[13].Karlík M., Siegl J., Slámová M., Birol Y., Study of the Damage of AA 8006 Twin-roll Cast Thin Sheets During Forming of Heat 
Exchanger Fins, Materials Science Forum, Trans Tech Publ, 2000, pp. 619-624.

[14].Kurt K., Dursun A., Dilsizoğlu B., Anger G., Ürgen M., Comparison of the Corrosion Behaviors of Twin-Roll Cast and DC Cast AA 6016 and AA6082 for Automotive Applications, TMS, 2006.

[15].Cieslar M., Poková M., Annealing Effects in Twin-Roll Cast AA8006 Aluminium Sheets Processed by Accumulative Roll-Bonding, Materials, 7-12 (2014) 8058-8069.

[16].[Trakov M.V.I.K.L., Mechanical and Corrosion Properties of AA8011 Sheets And
Foils, Materiali in Tehnologije, 40-3 (2006) 83-88.

[17].Valjema A.U.M.D., Analysis of Twin-Roll Casting AA8079 Alloy 6.35- $\mu \mathrm{m}$ Foil Rolling Process, Analysis, 50-6 (2016) 861- 868.

[18].Nisancioglu K., Holtan H., Measurement of the Critical Pitting Potential of Aluminium, Corrosion Science, 18-9 (1978) 835-849.

[19].Standards A.S.T.M., ASTM G69-12, Standard Test Method for Measurement of Corrosion Potentials of Aluminum Alloys, Philadephia, 2003. 